reduce needless repetition of blood counts in cases at present considered borderline.

The following ranges (expressing cells per cu.mm. of blood) are propcsed, and for comparison the current ranges are given in brackets: total leucocyte count, 4,000-11,500 (4,000$10,000)$; neutrophils, $2,000-7,500$ (2,500-7,500) ; lymphocytes, $1,000-4,000(1,000-3,500)$; monocytes, $200-1,000$ (200-800).

The A.E.R.E. report does not doubt that the figures usually quoted are sufficiently good in ordinary clinical practice, but it points out that it is advisable for the industrial medical office - to know the normal ranges for a particular population in order to make relevant decisions. A blood count is still used as part of the screening procedure in the pre-employment medical examination of a designated person, and it is carried out at the discretion of the medical adviser as part of the annual examination of the classified radiation worker. However, it is pointed out that experience has shown that the ordinary blood count is not a sufficiently delicate indicator for the detection of minor damage to individuals exposed to low-dosage irradiation. The results given in the A.E.R.E. report show that there was very little difference in the mean values for total leucocytes, lymphocytes, and monocytes in the exposed and non-exposed groups of workers. The mean neutrophil count was a little lower and the mean eosinophil count rather higher in the group exposed to radiation, but it is unlikely that this reflects actual exposure to radiation. Most of the workers with eosinophilia gave a history of allergy and had had negligible exposure. Perhaps the main reason for doing blood counts in radiation establishments is to detect those persons whose blood counts are distinctly outside the normal range before they are employed in such work.

The normal ranges given in the A.E.R.E. report are those for adults in European populations and are not necessarily applicable to other population groups. The neutrophil count tends to be lower in Africans and in West Indians, and for them it may be desirable to establish their own normal range. Though the data are of undoubted interest, it would be useful to have more information than is provided, especially in those instances where the counts were well outside even the proposed normal ranges. For example, the highest value for the neutrophil count was just over 20,000 per cu. $\mathrm{mm}$. and the lowest 700 per cu. mm., and for the lymphocyte count the highest value was 6,900 per cu. $\mathrm{mm}$. and the lowest 270 per cu. $\mathrm{mm}$. Were the people from whom these figures were obtained clinically normal at the time of the examination, and what was found on follow-up ?

\section{Library Sale}

On 10 and 11 February Sotheby's are to begin the sale by auction of some books from the library of the Royal Medical Society, Edinburgh. Further sales from this collection will be held later in the year. At first sight there may seem to be nothing unusual in a library selling off its surplus books, but this is no ordinary sale.

Founded in Edinburgh in 1737, the Royal Medical Society can proudly claim to be the oldest extant medical society in Great Britain. Its members and officers, with the exception of the treasurer, are undergraduates, and though it naturally

$$
1 \text { Gibbs, D. D., Brit. med. F., 1969, 1, } 242 .
$$

enjoys close links with the near-by medical school its premises and administration are independent. From its earliest years the society has received gifts of books for its library, and among some 10,000 volumes it now owns are many that are rare and valuable. Some date from the sixteenth century, such as Andreas Caesalpinus's De Plantis Libri (first edition), said to be the first book proposing a systematic classification of plants. From the early eighteenth century comes a rare essay by Sir John Floyer on the first use of the watch to count the pulse, which was discussed recently by D. D. Gibbs in his account of Floyer's life. ${ }^{1}$ First editions and complete sets of medical and scientific classics are also well represented. All told, it is possible that this sale might realize something like $£ 100,000$.

The decision to sell such a magnificent collection cannot have been lightly taken, however regrettable it must seem to medical men and historians in addition, no doubt, to the members of the society. The finances of an undergraduate society are naturally rather fragile, and the mere cost of preserving in good health such a collection of books, as well as insuring it, must be exceedingly great. Moreover, the society has had to vacate its premises and find a new home. Clearly it has become burdened with a treasure which, while increasing in value as the years go by, demands more spending on its upkeep than the society can afford. An appeal launched a few years ago for funds to help the society find new accommodation presumably did not bring in enough to avert at the same time what many people must regard as a sad end to an exceptionally fine collection.

Many of these books will go abroad, and the society deserves some congratulation for deciding to auction them instead of accepting private offers it must have had from the U.S.A. and probably elsewhere. At least British libraries will have the opportunity of competing for them within their all too limited resources. But no one with a respect for books and the learning they embody can contemplate without regret a sale of this magnitude-described by Sotheby's as "the largest medical library to pass through its hands in living memory." It is unfortunate that insufficient help has come to preserve it.

\section{Spontaneous Pneumothorax and Menstruation}

In 1958 E. R. Maurer, J. A. Schaal, and F. L. Mendez ${ }^{1}$ reported on a patient with recurring spontaneous pneumothorax concomitant with menstruation. Twelve further examples of this syndrome have now been described, nine of them within the last two years. ${ }^{2-7}$ Several features are common to each of these thirteen patients. All were in the fourth decade of life, the pneumothorax invariably appeared on the right side within a day or two of the onset of menstruation, and there was a remarkable tendency to recurrence. In all, 195 attacks of pneumothorax were recorded (an average of 14 attacks in each patient), and most of them were con-

\footnotetext{
1 Maurer, E. R., Schaal, J. A., and Mendez, F. L., jun., f. Amer. med.

Ass., 1958, 168, 2013 .

s Mayo, P., f. thorac. cardiovasc. Surg., 1963, 46, 415.

- Kovarik, J. L., and Toll, G. D., f. Amer. med. Ass., 1966, 196, 595.

5 Collins, T. F. B., S. Afr. med. F., 1967, 41, 391.

- Crutcher, R. R., Waltuch, T. L., and Blue, M. E., f. thorac. cardiovasc. Surg., 1967, 54, 599.

, Davies, R., Thorax, 1968, 23, 370.

' Davies, R., Thorax, 1968, 23, 370.

- Brit. med. f., 1968, 1, 720.
} 